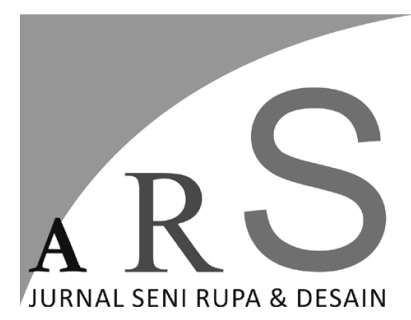

Volume 21 Nomor 2-Agustus 2018

\section{DESAIN INTERAKSI PADA UANG RUPIAH KERTAS EMISI 2016}

\author{
A. Sobi Mutohari \\ Prodi S2 Desain, Fakultas Seni Rupa dan Desain \\ Institut Teknologi Bandung \\ Email: sobymutohary@gmail.com
}

\begin{abstract}
ABSTRAK
Uang rupiah emisi 2016 sudah beredar di masyarakat selama hampir satu tahun lamanya. Berdasarkan survei penulis mayoritas masyarakat sering tertukar ketika menggunakan uang rupiah emisi baru ini. Uang yang sering tertukar adalah pecahan Rp 2000 dan Rp 20000. Menggunakan premis desain interaksi penulis menganalisis elemen-elemen bentuk dari disiplin desain grafis pada uang rupiah emisi 2016. Kajian ini menggunakan metode pengumpulan data survei kuesioner daring dan data materi visual, data yang telah terkumpul kemudian diinterpretasikan menggunakan analisis pendekatan estetika dengan membahas elemen-elemen visual dalam objek desain uang emisi 2016. Hasil yang diperoleh dari kajian ini adalah berupa analisis kualitatif tentang desain uang emisi 2016 dan faktor-faktor elemen bentuk apa saja yang membuat masyarakat sering tertukar ketika menggunakan uang ini.
\end{abstract}

Kata Kunci: Desain Interaksi, Desain grafis, Uang.

\begin{abstract}
2016 Rupiah's cash emission was already used by people for almost a year. Based on reseacher's survey most of Rupiah's user was ever mistaken when it comes to distinguish one nominal to another. The user was confused between Rp 2000 and the Rp 20000 one. By using interaction design premise the researcher analyze the aesthetic elements in 2016 Rupiah's cash emission. This research collected data by online survey and visual material. Those collected data interpreted using aesthetic approach by analyzing visual elements in the 2016 Rupiah's cash emisson. This research resulted qualitative data analysis about the money design and aesthetic elements that influencing confused user when using this money.
\end{abstract}

Keywords: Interaction Design, Graphic Design, Cash 


\section{Pendahuluan}

Pada tahun 2016 bulan Desember lalu Pemerintah menerbitkan uang emisi baru, uang Rupiah emisi 2016. Emisi ini mendapat pro dan kontra serta berbagai pendapat dari masyarakat. Berawal dari pengalaman pribadi yang pernah tertukar antara uang pecahan $\mathrm{Rp} 2000$ dan Rp 20000 pada emisi ini, penulis kemudian membuktikan melalui survei apakah masyarakat lain juga pernah tertukar. Sebagai akademisi desain yang berfokus di bidang desain grafis penulis tertarik membahas permasalahan ini secara akademis.

Uang adalah salah satu objek desain grafis yang sangat akrab dalam keseharian masyarakat dan dipakai secara luas. Uang adalah alat tukar yang membantu manusia untuk bertransaksi dan menyimpan kekayaan. Ketika membeli sesuatu manusia modern menggunakan uang sebagai alat tukarnya, uang menjadi objek perantara antara manusia satu dengan lainnya. Di dalam uang terdapat nilai, berbeda nominal uang berbeda pula nilai uangnya, di titik inilah desain uang menjadi penting. Desain uang tidak hanya untuk berindah-indah secara visual namun juga memiliki tanggung jawab desain interaksi. Di masa modern ini uang memiliki berbagai bentuk yaitu berupa kas atau tunai, saldo bank, surat berharga, cek dan uang virtual seperti bitcoin. Pada kajian ini penulis membatasi hanya akan membahas uang tunai Rupiah Indonesia emisi 2016 yang berbahan kertas.

Pembahasan soal uang dapat beragam tergantung dari konteks dan disiplinnya. Uang dapat dibahas dari konteks filsafat yang mempertanyakan ulang sistem tukar dengan uang, uang juga tentu dapat dibahas melalui disiplin ilmu ekonomi, sosial hingga desain. Kajian ini fokus membahas uang dari konteks disiplin desain, khususnya melalui premis desain interaksi dengan dasar-dasar keilmuan desain grafis pada uang kertas Rupiah emisi 2016.

Berdasarkan data survei yang penulis dapat pada sampel responden Warga Negara Indonesia mayoritas pengguna (61.62\%) ketika menggunakan uang rupiah emisi 2016 pernah tertukar antara pecahan satu dan lainnya. Dalam perspektif desain interaksi ini merupakan masalah besar karena Desain interaksi mempunyai banyak tujuan, salah satu yang paling penting adalah mengurangi aspek negatif seperti frustasi dan kejengkelan penggunanya. (Rogers, Sharp \& Preece, 2015). Tertukar, dalam konteks penggunaan uang adalah salah satu aspek negatif dan apabila terjadi berulang kali akan menimbulkan kejengkelan pengguna. Ketika pengguna tertukar saat menggunakan uang Ia dapat pula merugi secara ekonomi karena apa yang Ia bayar tidak sama dengan nilai yang Ia konsumsi.

Masalah uang dan kejengkelan pengguna menjadi lebih parah karena uang bersifat Nasional dan lebih sulit untuk diperbarui dalam waktu yang singkat dibandingkan dengan aplikasi dan laman web. Uang diperbarui sekitar 10 tahun sekali, maka desain uang perlu sangat diperhatikan secara detail untuk menghindari kesalahan-kesalahan. Karena belum adanya bahasan akademis soal permasalahan ini, dalam kajian ini penulis akan membahasnya dengan memaparkan data tentang kesalahan desain interaksi pada uang emisi 2016 kemudian menganalisis melalui elemen-elemen bentuk untuk mengidentifikasi letak kesalahan tersebut. Kajian ini memiliki dua pertanyaan dari yang bersifat umum sampai dengan yang bersifat khusus, dua pertanyaan tersebut adalah: pertama, bagaimana efektifitas desain interaksi ketika masyarakat menggunakan uang kertas emisi 2016; kedua, apa saja faktor elemen bentuk yang membuat uang rupiah pecahan $\mathrm{Rp}$ 2.000 dan Rp 20.000 sering tertukar. Kajian ini memiliki dua tujuan, yaitu memaparkan efektifitas desain interaksi pada uang rupiah emisi 2016 berdasarkan pengalaman pengguna dan mengidentifikasi faktor berupa elemen visual yang membuat uang pecahan $\mathrm{Rp} 2.000$ dan $\mathrm{Rp}$ 20.000 sering tertukar. Kajian ini diharapkan dapat memberikan gambaran bagi desainer grafis agar dapat mempertimbangkan faktor desain interaksi saat mendesain. Juga menambah pengetahuan dan wawasan dalam bidang desain interaksi dan desain grafis bagi rekan se-profesi dan bagi penulis sendiri.

\section{Pendekatan Kajian \\ Metode Pengumpulan data}

a. Survei daring

Survei daring menggunakan kuesioner 


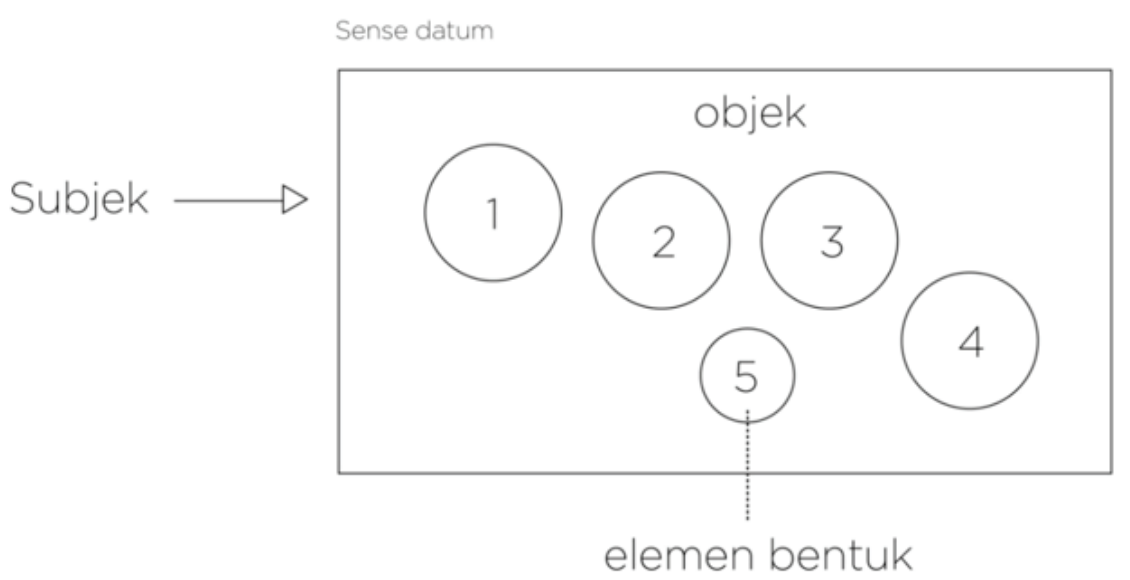

Gambar 1. Pendekatan Estetika

ini berguna untuk menangkap kecenderungan pengguna uang rupiah emisi 2016. Kecenderungan tersebut meliputi apakah sering tertukar ketika menggunakan uang rupiah kertas emisi 2016, lalu seberapa sering dan pecahan mana saja yang sering tertukar. Respondennya adalah sampel acak dari pengguna uang rupiah emisi 2016. Hasil dari data ini kemudian nantinya dianalisis secara kualitatif dengan pendekatan estetika. W. Vanderstoep dan D. Johnston (2009) menyebutkan bahwa survei berbasis web memiliki kelebihan seperti ramah pengguna dan praktis serta dapat menghemat biaya survei. Survei daring ini cocok untuk mahasiswa yang ingin menganalisis sesuatu dengan landasan data yang mencukupi.

b. Materi Visual

Materi visual berupa uang kertas emisi 2016 bersumber dari sumber-sumber daring dan laman resmi Bank Indonesia dalam kajian ini berguna untuk representasi uang riil, yang kemudian dianalisis elemen-elemen visualnya dalam kajian ini.

\section{Metode Analisis Data}

Pendekatan Estetika

Wiyancoko (2017) dalam kuliahnya menjelaskan bahwa salah satu pendekatan yang menekankan aspek seni dan desain yang berkaitan dengan elemen bentuk yang dianalisis oleh peneliti sebagai subjek salah satunya disebut dengan pendekatan estetika.

Elemen bentuk yang dianalisis dalam kajian ini adalah elemen bentuk yang berkaitan erat dengan bidang grafis, pertama adalah elemen bentuk yang tidak terlihat (intangible) yaitu tata letak (layout) yang di dalamnya terdapat struktur grid dan alur baca (sequence); kemudian yang terlihat (tangible) seperti warna, ilustrasi dan tipografi. Elemen-elemen bentuk bersifat grafis tersebut dipilih karena objek desain yang dipilih adalah objek desain yang berbentuk grafis yaitu uang.

\section{Pembahasan \\ Definisi Desain Interaksi}

Desain interaksi adalah istilah yang cukup sering digunakan untuk membahas objek desain yang memiliki interaksi dengan penggunanya. Pada bagian ini penulis akan menjelaskan mengapa penulis memilih istilah Desain Interaksi untuk kajian ini. Sebenarnya Ada beberapa istilah lain selain desain interaksi untuk membahas ranah ini, salah satu yang umum dituliskan adalah desain pengalaman atau User Experience (UX). Garret dalam Rogers dkk. (2015) menjelaskan bahwa user experience (UX/desain pengalaman) adalah semua produk yang digunakan dan menghasilkan pengalaman penggunanya. Seperti botol kecap, Koran dan lain sebagainya. Sementara istilah user experience (UX) ini sendiri masih menjadi polemik. (Cooper, Reimann, \& Cronin, 2007) Ia mengakui bahwa ada kemiripan antara mendesain toko fisik 
yang memberikan pengalaman pada konsumen dan mendesain toko fisik dengan produk yang interaktif. Istilah UX juga menjadi masalah karena pada dasarnya setiap desain memberikan pengalaman. Atas dasar kerancuan istilah desain pengalaman inilah penulis tidak menggunakan istilah desain pengalaman.

Selain desain pengalaman istilah lain yang juga sering digunakan adalah Arsitektur informasi, Cooper dkk. (2007) menjelaskan bahwa istilah Arsitektur informasi (information architectire/IA) muncul karena semakin maraknya World Wide Web atau penjelajah web. Arsitektur informasi berfokus pada navigasi di kebanyakan laman web.Objek desain yang penulis bahas adalah uang, maka istilah arsitektur informasi yang lebih erat dengan laman web tidak tepat apabila digunakan di kajian ini.

Ada juga yang sering menyebut disiplin yang membahas desain dan interaksi pengguna adalah desain antarmuka (User Interface/UI) Cooper dkk.Mengaku dalam bukunya Interaction designIa sering menggunakan istilah user interface untuk widget yang ada di atas layar gawai (Cooper dkk., 2007). Karena uang yang penulis bahas bersifat tercetak (cash) dan bukan di gawai (misalnya uang elektronik) maka rasanya kurang tepat apabila penulis menggunakan istilah desain antarmuka.

Penulis lebih memilih istilah desain interaksi pada kajian ini. Rogers dkk. (2015) menjelaskan bahwa desain interaksi adalah mendesain produk yang interaktif untuk mendukung manusia untuk berkomunikasi dan berinteraksi dalam kesehariannya. Penulis memilih istilah ini karena tendensi istilah desain antarmuka yang lebih mengarah ke layar dan gawai, begitu pula arsitektur informasi (Information Architecture) yang berfokus pada navigasi laman web sementara kajian ini membahas uang. Istilah desain pengalaman tidak dipilih karena seperti yang telah dijelaskan di atas, istilah desain pengalaman sendiri memiliki polemik. Penulis memilih istilah desain interaksi dengan alasan istilah ini cukup luas mengakomodir objek desain tidak hanya objek elektronik tetapi juga objek tercetak seperti uang yang penulis bahas. Saffer dalam Rogers dkk. berpendapat bahwa desain interaksi adalah seni memfasilitasi interaksi antar manusia melalui produk atau layanan. (2015). Dari pendapat Saffer di atas dapat disimpulkan bahwa uang adalah termasuk dalam ranah desain interaksi karena uang memfasilitasi interaksi antar manusia. Uang menjadi medium antar-manusia yang bertransaksi.

\section{Uang Rupiah kertas emisi 2016}

Uang Rupiah emisi 2016 berdasarkan liputan tempo.co (2016) adalah uang rupiah yang pertama diterbitkan pada 2016 oleh Bank Indonesia, uang ini dicetak oleh Perusahaan Umum percetakan Uang Republik Indonesia (Peruri) Karawang. Sebelum uang emisi 2016 diterbitkan, masyarakat Indonesia menggunakan uang Rupiah emisi 2006 sebagai alat tukar tunainya.

Bank Indonesia pada laman web resminya (2016) merilis dokumen zip yang berisi gambar ciri uang Rupiah emisi 2016. Seluruh uang kertas emisi 2016 berbahan kertas khusus yang terbuat dari serat kapas. ukuran uang Rp 1000 adalah $141 \mathrm{~mm}$ x $65 \mathrm{~mm}$, warna dominan hijau, gambar utama Tjut Meutia (bagian depan), bagian belakangnya tari tifa, pemandangan alam Banda Naira dan Bunga Anggrek Larat. Uang kertas pecahan Rp 2000 memiliki dimensi yang sama dengan pecahan Rp 1000 namun warna dominan pada uang ini adalah abu-abu, gambar utama Mohammad Hoesni Thamrin lalu dibelakangnya adalah tari piring, pemandangan alam Ngarai Sianok dan bunga jeumpa. Uang kertas pecahan Rp 5000 memiliki dimensi yang lebih besar yaitu $143 \mathrm{~mm}$ x $65 \mathrm{~mm}$, warna dominannya adalah cokelat, gambar utama Dr. K.H. Idham Chalid dibelakangnya terdapat gambar tari gambyong, pemandangan alam Gunung Bromo dan bunga sedap malam. Uang kertas pecahan $\mathrm{Rp} 10.000$ memiliki ukuran $145 \mathrm{~mm}$ x $65 \mathrm{~mm}$ dengan warna dominan ungu, Gambar utamanya adalah Frans Kaisiepo dibelakangnya terdapat gambar tari pakarena, pemandangan alam Taman Nasional Wakatobi dan bunga cempaka hutan kasar. Uang kertas pecahan Rp 20.000 berukuran 147 mm x $65 \mathrm{~mm}$, warna dominan hijau, gambar utama Dr. G. S. S. J. Ratulangi, dibelangnya adalah gambar tari gong, Pemandangan alam Derawan dan bunga anggrek hitam. Uang kertas pecahan Rp 50.000 berukuran $149 \mathrm{~mm}$ x $65 \mathrm{~mm}$ dengan 
Sebanyak $\mathbf{6 1 . 6 2} \%$ responden ketika menggunakan uang emisi 2016 pernah tertukar antara pecahan satu dan lainnya

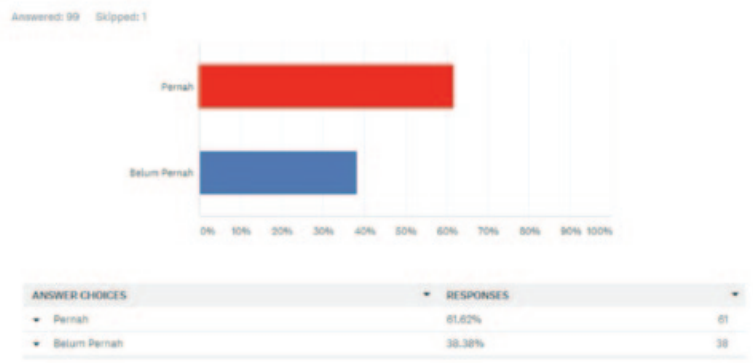

Gambar 2. Survei pengalaman desain interaksi uang rupiah emisi 2016
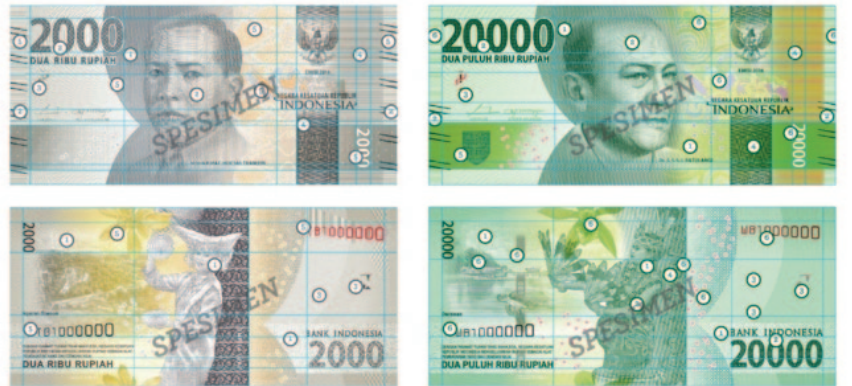

Gambar 4. Struktur grid dan uang kertas

warna dominan biru, gambar utamanya adalah Ir. H. Djuanda Kartawidjaja, dibelakangnya terdapat gambar tari legong, pemandangan alam Taman Nasional Komodo dan bunga jepun Bali. Uang kertas pecahan Rp 100.000 berukuran 151 $\mathrm{mm} \times 65 \mathrm{~mm}$ warna dominan merah, gambar utama Dr. (H.C.) Ir. Soekarno dan Dr. (H.C.) Drs. Mohammad Hatta, dibelakangnya terdapat gambar tari topeng Betawi, Pemandangan alam Raja Ampat dan bunga anggrek bulan.

\section{Masalah desain interaksi pada uang kertas Rupiah emisi 2016}

Uang kertas Rupiah emisi 2016 dalam konteks desain interaksi memiliki masalah serius. Dari data survei yang penulis dapat pada sampel responden Warga Negara Indonesia, mayoritas pengguna (61.62\%) ketika menggunakan uang rupiah emisi 2016 pernah tertukar antara pecahan satu dan lainnya. Dari perspektif desain interaksi hal-hal yang membuat pengguna frustasi adalah suatu kesalahan, pada konteks ini ke-frustasian pengguna dapat muncul karena tertukarnya uang. Ketika ditanya soal intensitas tertukarnya

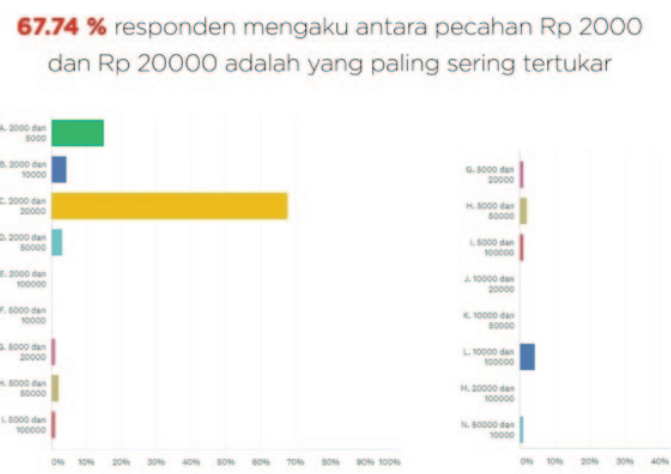

Gambar 3. Survei pengalaman desain interaksi uang rupiah emisi 2016

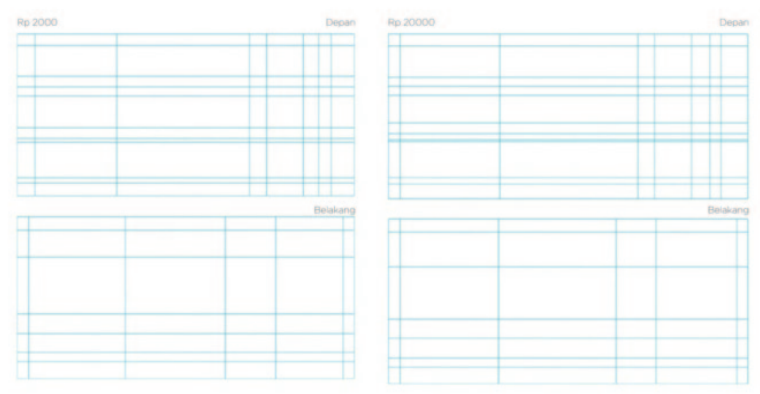

Gambar 5. Struktur grid uang pecahan Rp 2000 dan Rp 20000

uang kertas rupiah emisi $201626.37 \%$ menjawab pernah (sesekali) tertukar, 58.24\% jarang tertukar (tidak kerap kali), 13.19\% sering tertukar, 2.20\% sangat sering tertukar. Ini menunjukkan bahwa lebih dari setengah responden beberapa kali tertukar saat menggunakan uang Rupiah emisi 2016.

Di survei ini penulis mendapatkan data bahwa pecahan yang paling sering tertukar adalah antara pecahan $\mathrm{Rp} 2.000$ dan pecahan Rp 20.000 dengan $67.74 \%$. Sementara $15.05 \%$ responden menjawab bahwa mereka tertukar antara pecahan $\mathrm{Rp} 2.000$ dan Rp 5.000, 4.30\% tertukar antara pecahan $\mathrm{Rp} 2.000$ dan $\mathrm{Rp} 10.000$, $4.30 \%$ tertukar antara pecahan $\mathrm{Rp} 10.000$ dan Rp 100.000, $3.23 \%$ tertukar antara pecahan Rp 2.000 dan 50.000 dan sisanya sebanyak $1.08 \%$ tertukar antara pecahan $\mathrm{Rp} 50.000$ dan Rp 10.000. Pecahan Rp 2.000 dan Rp 20.000 paling sering tertukar padahal uang pecahan $\mathrm{Rp}$ 2.000 berdasarkan data penulis adalah pecahan yang paling sering digunakan dalam keseharian responden.

Tertukarnya pecahan satu dan lainnya tentu 

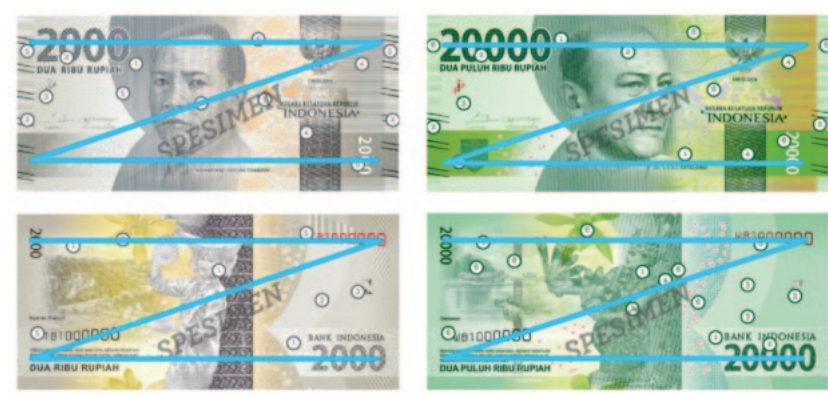

Gambar 6. Alur baca uang

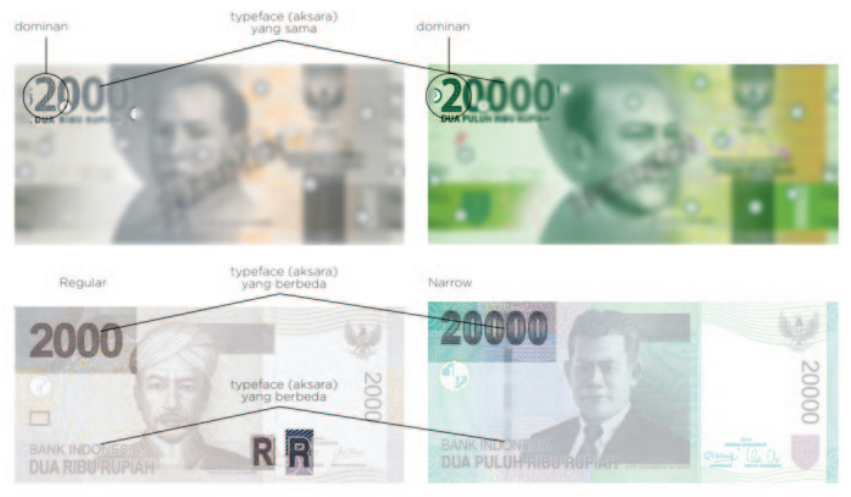

Gambar 7. Analisis Tipografi

memiliki alasan, Penulis mengidentifikasi secara kualitatif melalui disiplin desain grafis dengan menganalisis elemen-elemen visualnya mengapa pecahan antara Rp 2.000 dan Rp 20.000 paling sering tertukar oleh pengguna. Penulis menganalisis tata letak, tipografi dan warna pada uang kertas emisi 2016 untuk memaparkan alasan uang tersebut sering tertukar.

\section{Analisis tata letak (layout)}

Pada bagian ini penulis akan membahas dua hal, pertama adalah grid, yang ke-dua adalah alur baca atau sequence.

\section{Grid}

Vignelli mengemukakan bahwa dalam konteks pengorganisasian informasi, grid merepresentasikan struktur utama desain grafis. Grid membantu untuk mengatur konten, menjaga konsistensi dan grid membuat suatu desain menjadi terlihat teratur. (Vignelli, 2010). grid merupakan sesuatu yang sangat esensial karena ia adalah struktur, seperti bangunan apabila strukturnya baik maka akan baik dan terorganisir pula bangunan yang dihasilkan. Begitu pula dengan struktur grid pada desain grafis, apabila strukturnya sama maka output desainnya-pun secara pengaturan (organizing) akan mirip. Grid bersifat intangible atau tidak terlihat namun ia yang paling berpengaruh dalam mengatur sesuatu yang terlihat (tangible) seperti tipografi, ilustrasi dan warna.

Gambar 4 menunjukkan struktur grid pada uang kertas Rp 2000 dan Rp 20000 emisi 2016 di atas uang kertas itu sendiri, sementara gambar selanjutnya yaitu gambar 5 adalah struktur grid saja tanpa latar uang kertasnya. Dari grid di gambar dapat dianalisis bahwa keduanya secara struktural mirip. Misalnya dalam mengorganisir tipografi nominal “ $\mathrm{Rp} 20000$ ” dan “Rp 2000" pada bagian depan uang, keduanya menempatkan ukuran yang lebih besar secara horisontal di kanan atas, sementara di kiri bawah keduanya sama-sama menempatkan tipografi yang lebih kecil dengan vertikal. Pengorganisiran yang serupa juga terjadi pada bagian belakang uang, tipografi yang lebih kecil secara vertikal ditempatkan di kiri atas, sementara kanan bawah tipografi yang lebih besar. Ilustrasi secara struktur juga ditempatkan sama-sama di bagian tengah uang baik depan maupun belakang uang.

\section{Alur Baca (Sequence)}

Berdasarkan dari kajian oleh Dr. Mario R. Garcia dan Pegie Stark pada tahun 2007 dalam Rustan (2008) bahasa yang digunakan mempengaruhi cara manusia membaca suatu objek desain grafis. Misalnya pada pengguna bahasa dan tulisan latin orang membaca diawali dari kiri ke kanan. Namun Rustan (2008) menambahkan bahwa itu bukan faktor satusatunya manusia dalam alur baca, ada juga faktor pemberian emphasis yaitu pembedaan suatu objek seperti pembedaan warna, ukuran, penggayaan (style) dan lainnya.

Indonesia adalah Negara yang menggunakan abjad latin sebagai tulisannya. Masyarakat Indonesia membaca dari kiri ke kanan. Namun untuk alur baca objek desain grafis khususnya pada kasus uang kertas emisi 2016 ini kita harus periksa terlebih dahulu. Pada desain uang kertas emisi 2016 bagian depan tipografi yang menonjol adalah tipografi nominal di bagian kiri atas. Dari tipografi yang ukurannya besar ini dapat dikonfirmasi bahwa emphasis terjadi di ukuran 

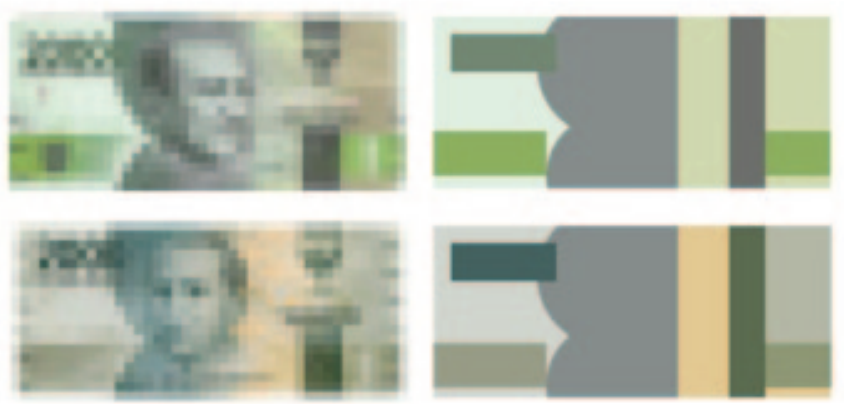

Gambar 8. Analisis warna bagian depan
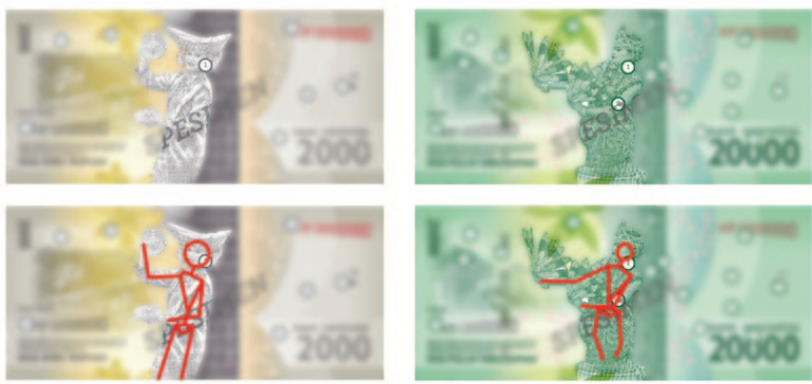

Gambar 10. Analisis ilustrasi bagian belakang

tipografi nominal sebagai penekanan alur baca dari kiri ke kanan. alur baca pada uang kertas emisi 2016 ini adalah dari kiri ke kanan dengan bentuk huruf ' $Z$ '.

\section{Analisis Tipografi}

Berdasarkan premis alur baca di atas dapat diasumsikan bahwa bagian paling pertama yang dibaca adalah yang paling penting dan menonjol. Dengan pertimbangan bahwa orang bertransaksi secara cepat (satu sampai dua detik) dapat diambil kesimpulan bahwa bagian yang menonjol menjadi penting dan krusial-dalam hal ini tipografi nominal uang. Berdasarkan buku Kane (2011) penulis mengkategorikan aksara utama pada uang emisi 2016 bertipe condensed sans serif, yaitu tegak dan tanpa kait pada huruf-hurufnya.

Angka "2" pada kedua uang kertas yang paling sering tertukar ini adalah angka yang paling dominan di antara bagian-bagian lain berdasarkan teori yang telah penulis sampaikan. Kedua angka ini menjadi sering tertukar karena typeface keduanya sama. Secara susunan angka, kedua nominal di atas hanya dibedakan oleh satu buah ' 0 ', sementara secara visual typeface keduanya sama, inilah salah satu faktor yang membuat keduanya sering membingungkan pengguna. Mari kita bandingkan dengan
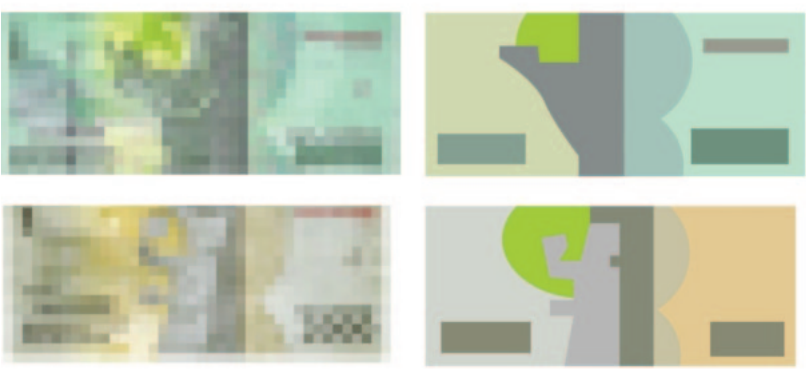

Gambar 9. Analisis warna bagian belakang

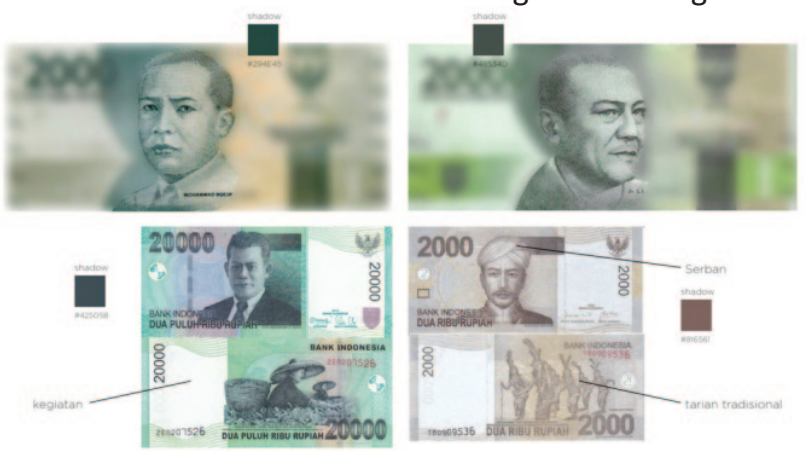

Gambar 11. Analisis ilustrasi bagian depan

emisi sebelumnya yang menggunakan typeface berbeda, meskipun keduanya hanya dibedakan dengan satu buah angka ' 0 ' juga namun dengan perbedaan typeface perbedaannya menjadi kentara secara visual sehingga pengguna dapat membedakan kedua uang ini dengan mudah.

\section{Analisis Warna}

Lidwell, Holden dan Butler (2010) menjelaskan bahwa warna digunakan untuk membuat perhatian (attraction), mengindikasikan pesan dan meningkatkan estetika. Dalam konteks uang kertas ini saya mengkategorikan penggunaan warna ditujukan untuk meningkatkan estetika. Masalah muncul ketika uang digunakan di kehidupan seharihari, kemudian ada banyak nominal, dari yang kecil sampai yang besar, kebutuhan untuk membedakan secara visual setiap nominal menjadi penting. Pada titik ini masing-masing nominal uang mempunyai kebutuhan "identitas visual". Saya rasa perlu untuk menggunakan teori sequence of cognition atau rangkaian keterlihatan, Wheeler (2009) menjelaskan bahwa rangkaian keterlihatan adalah ilmu tentang persepsi yang membahas bagaimana manusia mengenali dan menginterpretasi stimulus sensorik. Ia menerangkan bahwa otak pertama- 
tama mengetahui dan mengingat bentuk (shape) terliebih dahulu, kemudian warna dan terakhir adalah kesatuan dari keduanya yaitu form.

Warna adalah bagian penting untuk membedakan masing-masing nominal uang berdasarkan teori rangkaian keterlihatan. Untuk membedakan masing-masing uang tentu harus membedakan warnanya. Pada nominal uang Rp 2000 dan Rp 20000 emisi 2016 sudah ada upaya untuk membedakan warna namun kedua warna ini secara keterlihatan masih mirip.

Dalam analisis ini penulis menyederhanakan warna secara keseluruhan saja. Dapat dilihat bahwa secara keseluruhan kedua desain uang ini dapat dibagi menjadi tiga, bagian kiri, tengah dan kanan. Bagian kiri keduanya berwarna mirip, kemudian bagian tengah warnanya juga mirip dengan bentuk (shape) serupa yaitu gabungan dua setengah lingkaran dan persegi. Pada bagian kanan keduanya sama-sama memiliki persegi panjang vertikal. Secara warna kedua desain uang pada bagian depan ini mirip sehingga menyulitkan pengguna dalam membedakan keduanya.

Kemiripan warna juga terjadi pada bagian belakang uang, meskipun tidak semirip bagian depan uang. Pada bagian belakang warna penari menjadi penting karena cukup berbeda antar satu dan lainnya. Namun pada bagian sebelah kanan cukup terlihat mirip dengan shape gabungan setengah lingkaran yang sama. Warna oranye di bagian tengah atas juga keduanya memiliki itu sehingga cukup membuat pengguna kebingungan

\section{Analisis Ilustrasi}

Hembree (2006) menyebut bahwa kelebihan ilustrasi adalah penggayaannya yang unik. Pada uang rupiah emisi 2016 penggayaan ilustrasinya adalah engraving atau ukiran. Pada bagian belakang uang ilustrasi yang ditampilkan adalah tari-tarian tradisional dari berbagai daerah di Indonesia.

Uang kertas emisi 2016 nominal Rp 2000 menampilkan tari piring yang berasal dari Minangkabau, sementara nominal Rp 20000 menampilkan tari gong, berasal dari suku Dayak. Yang menjadi sorotan utama dalam analisis ini adalah keduanya memiliki anatomi gerakan yang mirip dengan tangan kanan dan kiri yang mengarah ke kiri uang. Kedua penari dalam uang tesebut juga merendahkan posisinya dalam berdiri. Baik uang Rp 2000 dan Rp 20000 pada emisi 2016 ini menampilkan wanita yang mana secara anatomis manusia gender berpengaruh terhadap tampilan fisiknya-wanita mirip dengan wanita. Faktor ilustrasi bagian belakang uang ini juga menjadi faktor yang membuat desain interaksi pada uang rupiah emisi 2016 di kedua nominal ini membingungkan pengguna.

Bagian depan uang menampilkan tokoh Nasional, uang Rp 2000 emisi 2016 ilustrasi yang ditampilkan adalah Mohammad Hoesni Thamrin seorang tokoh pergerakan yang memiliki darah Betawi-Belanda, sementara untuk uang Rp 20000 yang ditampilkan adalah Dr. G. S. S. J. Ratulangi atau lebih dikenal sebagai Sam Ratulangi, seorang aktivis kemerdekaan asal Sulawesi Utara. Apabila dibandingkan, ilustrasi Mohammad Hoesni Thamrin dan Sam Ratulangi menghadap kearah yang berbeda, Mohammad Hoesni Thamrin ke sebelah kiri uang sementara Sam Ratulangi ke sebelah kanan uang. Namun apabila dibandingkan dengan uang emisi sebelumnya, jelas uang emisi sebelumnya dalam hal ilustrasi tokoh lebih tinggi tingkat diferensiasinya. Pada uang emisi 2006 yang ditampilkan pada nominal Rp 20000 adalah Oto Iskandar Dinata dengan pakaian Jas resmi. Dalam nominal Rp 2000 yang ditampilkan adalah Pangeran Antasari dengan pakaian tradisional dan aksesoris serban, aksesoris ini menjadi sangat krusial dalam hal diferensiasi karena ini menjadi pembeda yang kuat antara tokoh pada uang $\mathrm{Rp}$ 20000 dan Rp 2000, diferensiasi aksesoris tidak terjadi pada uang emisi 2016 yang cenderung mirip tokohnya. Emisi 2006 diferensiasinya dipertajam juga oleh kumis di Pangeran Antasari, sementara Oto Iskandar Dinata bersih tanpa kumis sehingga kedua tokoh ini secara visual semakin terlihat berbeda. Pada uang emisi 2016 keduanya tidak memiliki kumis, keduanya juga tidak menampilkan janggut dan keduanya memiliki potongan rambut yang mirip yang membuat dua tokoh yang ditampilkan ini serupa. Tampilan visual tokoh kedua ilustrasi emisi 2016 cenderung mirip dan rendah diferensiasinya dibanding uang emisi sebelumnya.

Uang emisi 2006 ilustrasi belakangnya 
cenderung beragam, pada nominal Rp 2000 ilustrasinya menampilkan tarian adat dayak dan nominal Rp 20000 menampilkan pemetik teh. Menari dan memetik teh adalah kegiatan yang sangat berbeda apabila dibandingkan dengan emisi 2016 yang seluruhnya menampilkan taritarian daerah. Dari warna shadow ilustrasi juga kontrasnya dapat dibandingkan antara emisi 2016 yang tidak kontras antar satu dan lainnya dengan emisi 2006 yang sangat kontras shadow satu dan lainnya. Bagian depan uang emisi 2016 pecahan Rp 2000 memiliki shadow dengan intensitas cyan sekitar $81 \%$, magenta $48 \%$, yellow 66\%, key 41\%, sementara pecahan Rp 20000 memiliki shadow dengan intensitas cyan 69\%, magenta 52\%, yellow 61\%, key 35\%. Emisi 2006 memiliki shadow yang lebih kontras, untuk uang Rp 2000 memiliki intensitas cyan sekitar 45\%, magenta 57\%, yellow 54\% dan key $18 \%$. Untuk pecahan Rp 2000 intensitas cyan sekitar 74\%, magenta $58 \%$, yellow $51 \%$ dan key $32 \%$. Shadow warna ilustrasi mempengaruhi warna uang secara keseluruhan maka pembedaan shadow adalah hal yang perlu diperhatikan untuk diferensiasi antar-uang.

\section{Kesimpulan}

Kajian menggunakan pendekatan estetika yang membahas elemen-elemen bentuk dalam desain uang Rupiah emisi 2016ini merujuk pada suatu kesimpulan, yang pertama adalah mayoritas pengguna pernah tertukar ketika menggunakan emisi ini, yang kedua yang menjadi bahasan adalah uang Rupiah pecahan Rp 2000 dengan Rp 20000 adalah uang yang paling sering tertukar, setelah diidentifikasi dan dianalisis penyebabnya memang dari elemen-elemen bentuk pada uang tersebut yang dirancang secara mirip, baik yang tak terlihat(intangible) seperti grid dan alur baca serta yang terlihat(tangible) seperti tipografi, ilustrasi dan warna.

\section{Saran}

Saran dari kajian ini terbagi menjadi dua yaitu bagi rekan se-profesi desain grafis dan saran untuk kajian lanjutan. Bagi rekan se-profesi desain grafis hendaknya mempertanyakan ulang tentang objek yang akan didesainnya, setiap objek memiliki tujuan dan cara pemakaian yang berbeda. Entitas desain uang jelas berbeda dengan poster yang bersifat sementara (ephemeral), uang digunakan secara lama, terus menerus dan interaktif. Uang termasuk ke dalam desain interaksi maka aspek yang perlu untuk diperhatikan adalah aspek-aspek yang membuat pengguna nyaman dan tidak frustasi. Dalam diskusi ini saya berpendapat bahwa diferensiasi antar-uang jauh lebih penting daripada konsistensi antaruang. Baik warna, ilustrasi dan tipografi dalam uang karena digunakan secara terus menerus dan dalam waktu yang lama mereka tersimpan dalam psikologis penggunanya. Kemudian saran untuk kajian lanjutan diantaranya adalah aspek lain yang juga perlu untuk diperhatikan seperti dimensi dan tekstur. Aspek kebiasaan pengguna dalam merespons objek uang juga menarik untuk dibahas pada kajian selanjutnya.

\section{Daftar Pustaka}

Cooper, A., Reimann, R., \& Cronin, D. (2007). About Face 3: The Essentials of Interaction Design. Indiana, United States of America: Wiley Publishing, Inc.

Hembree, R. (2006). The Complete Graphic Designer: A Guide to Understanding Graphics and Visual Communication. Massachusetts, United States of America: Rockport Publishers, Inc.

Kane, J. (2011). A Type Primer. London: Laurence King Publishing Ltd.

Lidwell, W., Holden, K., \& Butler, J. (2010). Universal Principles of Design. Massachusetts, United States of America: Rockport Publishers, Inc.

Preece, J., Sharp, H., \& Rogers, Y. (2015). Interaction Design: beyond human-computer interaction. West Sussex: John Wiley \& Sons Ltd.

Rustan, S. (2008). Layout, Dasar dan Penerapannya. Jakarta: Gramedia Pustaka utama.

W. Vanderstoep, S., \& D. Johnston, D. (2009). Research Methods for Everyday Life: Blending Qualitative and Quantitative Approaches. Market Street, San Francisco: Jossey-Bass A Wiley Imprint.

Wiyancoko, D. (2017). Pendekatan Kajian Desain. Lecture handout: Teori Desain. Bandung: Institut Teknologi Bandung. 